\title{
Teachers' Needs for Authentic Assessment to Assess Writing Skill at Grade $X$ of Senior High Schools in Tanah Datar
}

\author{
Kessy Pamela ${ }^{1}$, Refnaldi ${ }^{2}$, and M. Zaim ${ }^{3}$ \\ ${ }^{1}$ Universitas Negeri Padang, Padang, Indonesia, $ه$ (email),kessypamela8@gmail.com \\ ${ }^{2}$ Universitas Negeri Padang, Padang, Indonesia, $\triangle($ (email), refnaldi@yahoo.com \\ ${ }^{3}$ Universitas Negeri Padang, Padang, Indonesia, $ه$ (email), mzaim_unp@yahoo.com
}

\begin{abstract}
Authentic assessment as an important form of assessment that can demonstrate meaningful action of essential skills and knowledge to be performed in real situation, not only in learning process. Moreover, this article aims to find out the teachers' need on authentic assessment for assessing one of the productive skills in which writing skill of grade $\mathrm{X}$ at senior high schools in Tanah Datar. Since it is a survey research, the data were collected through administering questionnaire to 9 English teachers from 6 schools in Tanah Datar who teach students at grade $\mathrm{X}$. The questionnaire was focused on teachers' wants on authentic assessment to assess writing skill. The findings showed that (1) there were seven types of the authentic assessment for writing skill needed by teachers, they are writing with purpose, writing prompt, writing summary, writing sample, integrated language assessment, narrating sequence and picture cued description (performance), and portfolio (2) the topics needed for assessing writing were based on the 2013 curriculum, related, and close to students; and (3) teachers need scoring rubrics which includes organization, structure, content, vocabulary, and mechanics of writing. In short, the teachers need several kinds of authentic assessment which are appropriate for assessing students' writing skill.
\end{abstract}

\section{Keywords: Authentic Assessment, Teachers' Needs, Writing Skill}

\section{INTRODUCTION}

Authentic assessment as an important form of assessment can demonstrate meaningful action and activities of essential skills and knowledge to be performed in student's real situation (Mueller, 2011; Callison, 1998; O’Malley and Pierce 1996; Gulikers, 2004; $\&$ Stiggin, 1987). This kind of alternative assessment is necessary to see the students' achievement, learning, attitudes and motivation on student's activities instructionally. Thus, the existence of authentic assessment is proven when government required authentic assessment as the prominent assessment in assessing students' progress. (Permendikbud RI No. 104 2014).

Using authentic assessment is important since it can better facilitate teaching and learning, and measure students' English skills especially productive skills (Zaim, Refnaldi \& Moria, 2017; Rukmini \& Saputri, 2017). Teachers can implement authentic assessment in learning and teaching process since it can be used to measure and demonstrate students' skills, knowledge, and attitude and it also helps teachers to evaluate whether they have been success in the process of teaching and learning.

Moreover, authentic assessment can also inspire and motivate students to increase their skills and knowledge in the real situation (Lombardi, 2008). When implementing authentic assessment in classroom, students can use their skills and knowledge for performing good performances which are needed in the real world activities. So, what the students have got in the classroom can be used in the real world. It was also added by Lombardi (2008) in which he said the use of authentic assessment prompts the learners to perform certain tasks that will need the application of the knowledge learned and skills acquired.

As one of the productive skills in English, it is necessary to study students' writing through authentic assessment since students' will carry out the writing skills in the certain activities outside the classroom. To convince, there are numerous researchers who have studied authentic assessment in writing skill. Some studies are in the implemention authentic assessments. Some of them are Hayati, Bentri, \& Rahmi (2017) who have studied the analysis of the issues in implementing authentic assessment in the currciulum 2013; Noormaliyah who has studied the English teacher's implementation of authentic assessment at seventh grade of SMP Muhammadiyah Banjar Baru; Metin (2013) who has 
studied the difficulties of teachers in preparing and implementing performance task.

Furthermore, Rukmini \& Saputri (2017) has also conducted study on the assessment to evaluate English productive skills of students based on curriculum 2013. A study was also conducted by Zaim (2013) on implementation and problems of authentic assessment in the process of teaching and learning of English in some junior high schools in Padang; Idham, Nadrun \& Darmawan (2015) has also studied the implementation of authentic assessment in English writing skill to the students of grade 11. Beside, researches on the implementation of authentic assessment by English teachers have also conducted by Kurniatun, 2017 ; Fitri, 2017; and Natalia, Asib, \& Kristina, 2018. The other research is in the area of needs analysis of teacher in assessing writing as conducted by Refnaldi, Zaim \& Moria (2017).

In addition, there was also challenges, difficulties and problems in implementing authentic assessment. There are some obstacles and challenges due to the authentic assessment in implementing each skill as a research done by Suastra and Ristiadi (2017) who have conducted a research in science teaching. Beside, Fitriani (2014), Metin (2013), and Zaim (2013) have also conducted researches on the challenges or problems in actualizing authentic assessment in 2013 curriculum.

Specifically, studies on authentic assessment based on the school levels have been conducted. In primary school, a research was conducted by Noor \& Yusoff (2016), they studied how the process of writing is improved with the use of authentic assessment in English language classroom. Moreover, in junior high school level, related authentic speaking (Sahyoni, 2016) and writing assessment (Moria, 2017) had been developed. Besides, the curriculum in the school where they did research is different to the present research. They used KTSP curriculum or school-based curriculum (Kurikulum 2006). In senior high school level, Kurniatun (2017) had also studied authentic assessment of writing skills.

This research is necessary to be conducted since this research can be used to be an orientation to develop an authentic assessment model. This research revealed that the teachers' wants is really important to be studied since there were many teachers who did not understand the authentic assessment well, how to use and create rubric for assessing their students; and cannot use appropriate type of assessment to assess their students.

\section{METHOD}

This research is a survey research. The data were collected through questionnaire to 9 English teachers in Senior High Schools in Tanah Datar. All of the English teachers have taught English for grade X students. The questionnaire were designed with some indicators, but in this paper, the writer focused on the teachers' wants on authentic assessment for assessing students' writing skill. They were categorized into types of authentic assessment needed, topics needed and scoring rubrics needed. The data were analyzed through quantitative and qualitative data analysis.

\section{RESULT AND DISCUSSION}

The data of teachers' wants on authentic assessment were analyzed based on some indicators. There were three indicators explained in this paper, they are types of authentic assessment for writing skill, topics needed in assessing students' writing, and scoring criteria/rubric needed by teacher in assessing students' writing.

Before administering the questionnaire to teachers, the writer asked some question on authentic assessment that the teacher did in classroom. Some of the teachers said that they are familiar and implemented authentic assessment in the classroom. Meanwhile, some others also did not implement authentic assessment well. There were also some teachers who had implemented some types of authentic assessment in which they did not know the types of the assessment itself.

Moreover, the writer also asked about the way teacher assessed student's writing. Some of the teachers assessed writing using rubrics. Meanwhile, some others did not use some criteria to assess student's writing, for example, they just assessed student's text by analyzing student's grammar or structure and giving score based on the total errors of student's grammar. The teacher should have clear rubric which can ease them to assess student's writing.

Furthermore, the writer administered the questionnaire to each English teachers in 6 senior high schools in Tanah Datar. The first indicator that is needed to be explained is kinds of authentic assessment for writing skill needed by the teachers. There are several types of authentic assessment for writing skill based on O'Malley \& Pierce and Brown and Abeywickrama's opinions such as writing sample, writing prompt, writing summary, writing sample, writing conference, integrated language assessment, project/exhibition, experiment or demonstration, constructed respond items, observation, portfolio, performance, writing journal, self assessment, peer assessment, and process writing.

The table 1 . showed that there were 16 kinds of authentic assessment for writing skill provided in the questionnaire. After analyzing this indicator, it can be concluded that there were seven types of writing assessment that were highly needed to be assessed by the teacher. They are writing with purpose (3.56 point average), writing summary (3.44 point), writing prompt (3.33 point average), writing sample (3.56 point average), integrated language assessment (3.44 point average), portfolio, and performances (3.33 point average). The second indicator that was analyzed by the writer was the topic of writing skill that will be assessed by the teacher. The topics were developed by considering the English curriculum. 
Table 1. Authentic Assessment for Writing Skill

\begin{tabular}{|c|c|c|c|c|c|c|c|c|}
\hline \multirow{2}{*}{ No } & \multirow{2}{*}{ Types of Authentic Assessment } & \multicolumn{4}{|c|}{ Response } & \multirow{2}{*}{$\mathrm{T}$} & \multirow{2}{*}{ A } & \multirow{2}{*}{$\mathrm{C}$} \\
\hline & & SA & A & $\mathrm{D}$ & SD & & & \\
\hline 1 & Writing with purpose. & 20 & 12 & 0 & 0 & 32 & 3.56 & $\mathrm{VH}$ \\
\hline 2 & Writing prompt. & 16 & 12 & 2 & 0 & 30 & 3.33 & $\mathrm{VH}$ \\
\hline 3 & Writing summary. & 20 & 9 & 2 & 0 & 31 & 3.44 & $\mathrm{VH}$ \\
\hline 4 & Writing sample. & 20 & 12 & 0 & 0 & 32 & 3.56 & $\mathrm{VH}$ \\
\hline 5 & Writing conference. & 16 & 9 & 2 & 1 & 28 & 3.11 & $\mathrm{H}$ \\
\hline 6 & Integrated language assessment. & 16 & 15 & 0 & 0 & 31 & 3.44 & $\mathrm{VH}$ \\
\hline 7 & Project/exhibition. & 8 & 18 & 2 & 0 & 28 & 3.11 & $\mathrm{H}$ \\
\hline 8 & Experiment or demonstration. & 8 & 15 & 4 & 0 & 27 & 3.00 & $\mathrm{H}$ \\
\hline 9 & Constructed respond items. & 8 & 18 & 2 & 0 & 28 & 3.11 & $\mathrm{H}$ \\
\hline 10 & Observation. & 8 & 18 & 2 & 0 & 28 & 3.11 & $\mathrm{H}$ \\
\hline 11 & Portfolio. & 12 & 18 & 0 & 0 & 30 & 3.33 & $\mathrm{VH}$ \\
\hline 12 & Performance. & 12 & 18 & 0 & 0 & 30 & 3.33 & $\mathrm{VH}$ \\
\hline 13 & Writing journal. & 4 & 21 & 0 & 1 & 26 & 2.89 & $\mathrm{H}$ \\
\hline 14 & Self assessment. & 4 & 18 & 4 & 0 & 26 & 2.89 & $\mathrm{H}$ \\
\hline 15 & Peer assessment. & 4 & 24 & 0 & 0 & 28 & 3.11 & $\mathrm{H}$ \\
\hline 16 & Process writing. & 8 & 15 & 4 & 0 & 27 & 3.00 & $\mathrm{H}$ \\
\hline
\end{tabular}

Table 2. The Topic of Writing Skill

\begin{tabular}{|c|c|c|c|c|c|c|c|c|}
\hline \multirow{2}{*}{ No } & \multirow{2}{*}{ Topics } & \multicolumn{4}{|c|}{ Response } & \multirow{2}{*}{$\mathrm{T}$} & \multirow{2}{*}{ A } & \multirow{2}{*}{$\mathrm{C}$} \\
\hline & & SA & A & $\mathrm{D}$ & SD & & & \\
\hline 1 & Introducing self, friends, and parents topic. & 16 & 15 & 0 & 0 & 31 & 3.44 & $\mathrm{VH}$ \\
\hline 2 & Writing email topic. & 20 & 12 & 0 & 0 & 32 & 3.56 & $\mathrm{VH}$ \\
\hline 3 & Writing congratulation card. & 20 & 12 & 0 & 0 & 32 & 3.56 & $\mathrm{VH}$ \\
\hline 4 & $\begin{array}{l}\text { Expressing intentions of doing weekend/holiday/school } \\
\text { activities and school projects. }\end{array}$ & 16 & 15 & 0 & 0 & 31 & 3.44 & $\mathrm{VH}$ \\
\hline 5 & Describing ecotourism destination and historical building. & 20 & 12 & 0 & 0 & 32 & 3.56 & $\mathrm{VH}$ \\
\hline 6 & Describing recreational places. & 20 & 12 & 0 & 0 & 32 & 3.56 & $\mathrm{VH}$ \\
\hline 7 & Giving information to public through announcement. & 20 & 12 & 0 & 0 & 32 & 3.56 & $\mathrm{VH}$ \\
\hline 8 & Recounting an experience of meeting an idol/favorite singer. & 20 & 12 & 0 & 1 & 33 & 3.67 & $\mathrm{VH}$ \\
\hline 9 & Recounting historical events. & 20 & 12 & 0 & 0 & 32 & 3.56 & $\mathrm{VH}$ \\
\hline 10 & $\begin{array}{l}\text { Retelling about past events related to the life of prominent } \\
\text { figures. }\end{array}$ & 20 & 9 & 2 & 0 & 31 & 3.44 & $\mathrm{VH}$ \\
\hline 11 & Retelling folktales. & 20 & 9 & 2 & 0 & 31 & 3.44 & $\mathrm{VH}$ \\
\hline 12 & Retelling the lyrics/meaning of a song. & 20 & 12 & 0 & 0 & 32 & 3.56 & $\mathrm{VH}$ \\
\hline
\end{tabular}

Based on the Table 2 above, it can be seen that all of the topic of writing skill were needed to be assessed since all of the statement were agreed by the teacher. It was proven by the number of averages which were categorized as very high. The last indicator that had been analyzed by the writer was the scoring rubrics. There were some criteria for assessing writing. In this questionnaire, the writer considered five criteria for assessing writing, they are organization, structure of text, content of text, vocabulary, and mechanics.

The table 3 showed that all of the criteria that were considered by the writer to be put in the scoring rubrics were needed by the teachers. It was proven by the number of 3.33 point average of teachers who were strongly agreed to those criteria.

The result of this research was quite similar to the research done by Refnaldi, Zaim, and Moria (2017). In this research, the kinds of authentic assessment and also the topics needed by the teacher were varied. Although this two research studied about authentic assessment for writing skill, these researches had differences on the school level of study, the current study was done in senior high school level. Meanwhile, Refnaldi, Zaim, and Moria conducted study on junior high schools level. 
Table 3. The Scoring Rubrics for Writing Assessment

\begin{tabular}{|c|c|c|c|c|c|c|c|c|}
\hline \multirow{2}{*}{$\begin{array}{l}\mathrm{N} \\
\mathrm{o}\end{array}$} & \multirow{2}{*}{$\begin{array}{l}\text { Scoring } \\
\text { Criteria }\end{array}$} & \multicolumn{4}{|c|}{ Response } & \multirow{2}{*}{$\mathrm{T}$} & \multirow{2}{*}{ A } & \multirow{2}{*}{$\mathrm{C}$} \\
\hline & & $\mathrm{SA}$ & $\mathrm{A}$ & $\mathrm{D}$ & SD & & & \\
\hline 1 & Organization & 12 & 18 & 0 & 0 & 30 & 3.33 & $\mathrm{VH}$ \\
\hline 2 & $\begin{array}{l}\text { Structure of } \\
\text { text }\end{array}$ & 12 & 18 & 0 & 0 & 30 & 3.33 & $\mathrm{VH}$ \\
\hline 3 & Content of text & 12 & 18 & 0 & 0 & 30 & 3.33 & $\mathrm{VH}$ \\
\hline 4 & Vocabulary & 12 & 18 & 0 & 0 & 30 & 3.33 & $\mathrm{VH}$ \\
\hline 5 & Mechanics & 12 & 18 & 0 & 0 & 30 & 3.33 & $\mathrm{VH}$ \\
\hline
\end{tabular}

Related to the result of the study, Callison (1998:4) highlights that authentic assessment is an evaluation that consists of various kinds of measurements that reflect the students' achievement, learning, attitudes, and motivation in real situation outside learning. In the evaluation process of the students, it is needed to use some forms of performance measurement in which it should reflect the students' real abilities in performing their learning. The measurement itself should be relevant to their real world situation.

Furthermore, the authentic assessments must cover a number of important components notably; practicality, reliability and validity to get qualified assessment. The components can be stated as having good on the components above when conducting an assessment. O'Malley and Pierce (1996:19) emphasize some key components in authentic assessments namely reliability, rater training, validity, and performance standard. Related to the theory, it implies that scoring rubric is necessary in assessing process. The criteria in the scoring rubric should consist of some points such as organization, structure of text, vocabulary, content, and mechanics.

\section{CONCLUSION}

It is important for teachers to implement authentic assessment in learning and teaching process. This article specifically discusses the authentic assessment for writing. Furthermore, the result of the analysis showed that (1) there were seven kinds of authentic assessment for writing skill needed by teachers, they were writing with purpose, writing prompt, writing summary, writing sample, integrated language assessment, narrating sequence and picture cued description (performance), and portfolio (2) the topics needed for assessing writing were based on the 2013 curriculum, related, and close to students; and (3) teachers need scoring rubrics which includes organization, structure, content, vocabulary, and mechanics of writing. To sum up, the teachers need several types of authentic assessment that are appropriate in assessing students' writing skill.

\section{ACKNOWLEDGMENTS}

This article is written based on the developmental research on authentic assessment funded by Ministry of Research, Technology and Higher Education in 2019. The writers would like to express their appreciation to the teachers as the participants of this research.

\section{REFERENCES}

[1] Brown, H.D \& Abeywickrama, P. 2010. Language Assessment Principles and Classroom Practices (Second Edition). New York: Pearson Education, Inc.

[2] Callison, D. 1998. Authentic Assessment. Journal School Library Media Activities Monthly. Indiana University: Bloomington.

[3] Fitri, H.A.A. 2017. The Implementation of Authentic Assessment Skills by English Teachers in English Instruction Based on Curriculum 2013 In Academic Year 2016/2017. Online Published Thesis. IAIN Surakarta.

[4] Fitriani. 2014. The Challenges in Implementing Authentic Assessment in Curriculum 2013. The 61st TEFLIN International Conference: UNS Solo.

[5] Gulikers, J.T.M, Bastiaens, T.J \& Kirschaner, P.A. 2004. Perception of Authentic Assessment: Five Dimensions of Authenticity. Educational Technology Research and Development. Netherlands.

[6] Hayati, A, Bentri, A \& Rahmi, U. 2017. Analyzing the Issues in the Implementation of Authentic Assessment in the 2013 Curriculum. International Journal of Science and Research. ISSN (Online): 2319-7064.

[7] Idham, F.I, Nadrun \& Darmawan. 2015. The Use of Authentic Assessment in English Writing Skill to the Elevanth Grade Students. E-journal of English Language Teaching Society (ELTS) Vol. 3 No. 1. ISSN 2331-1841.

[8] Jordan, R.R. 1997. English for Academic Purposes: A guide and Resource Book for Teachers. Cambridge: Cambridge University.

[9] Kurniatun, D. Authentic Assessment in Writing Class for the Student of 11th Grade in SMA AlFirdaus and SMA N 2 Sukoharjo. Online Published Thesis: Universitas Muhammadiyah Surakarta.

[10]Lombardi, M.M. 2008. Making the Grade: The Role of Assessment in Authentic Learning. Educause Learning Initiative Paper 1.

[11]Metin, M. 2013. Teachers' Difficulties in Preparation and Implementation of Performace Task. Educational Sciences: Theory \& Practice13(3) pp. 1644-1673.

[12] Mueller, J. 2005. The Authentic Assessment Toolbox: Enhancing Student Learning through Online Faculty Development. Available at http://jolt.merlot.org/documents/vol1_no1_mueller 001.pdf 
[13] Moria, E, Refnaldi \& Zaim, M. 2017. Using Authentic Assessment to Better Facilitate Teaching and Learning: The Case for Students' Writing Assessment. Sixth International Conference on Languages and Arts Vol. 148 pp.333-337.

[14] Noor, M \& Yusoff, N.M. 2016. Improving Process Writing with the Use Authentic Assessment. International Journal of evaluation and Research in Education. Vol. 5 No. 3. ISSN: 2252-8822.

[15] Noormaliyah. Them Implementation of Authentic Assessment by English Teachers at Seventh Grade of SMP Muhammadiyah BanjarBaru. National Seminar Proceeding. STKIP PGRI Banjarmasin.

[16] O’Malley, J.M \& Pierce, L.V. 1996. Authentic Assessment for English Language Learners: Practical Approaches for Teachers. New York: Addison-Wesley Publishing Company.

[17] Refnaldi, Zaim, M, \& Moria, E. 2017. Teachers' Need for Authentic Assessment to Assess Writing Skill at Grade VII of Junior High Schools in Teluk Kuantan. Advances in Social Science, Education and Humanities Research (ASSEHR), volume 110 Fifth International Seminar on English Language and Teaching (ISELT 2017). Universitas Negeri Padang.

[18] Rukmini, D \& Saputri, L.A.D.E. 2017. The Authentic Assessment to Measure Students' English Productive Skills Based on 2013 Curriculum. Indonesian Journal of Applied Linguistics, Vol. 7 No. 2, pp. 263-273.

[19] Schurr, L.S. 2002. Authentic Assessment: Professional Reference for Teacher. Journal Teaching at Middle School.

[20] Stiggin, R.J. 1987. Revitalizing Classroom Assessment: The Highest Instruction Priority. Phi Delta Kappan.

[21] Suastra, I.W \& Ristiadi, N.P. 2017. Problem Faced by Teachers in Designing and Implementing Authentic Assessment in Science Teaching. International Research Journal of Engineering, IT \& Science Research Vol.3 Issue 4, pp. 24-32.

[22]Zaim, M. 2013. Asesmen Otentik: Implementasi dan Permasalahannya dalam Pembelajaran Bahasa Inggris di Sekolah Menengah. Paper presented at International Seminar on Language and Arts-2. Padang : FBS UNP. 